\title{
A new pest of tomato and other records of mealybugs (Hemiptera: Pseudococcidae) from Espírito Santo, Brazil
}

\author{
MARK P. CULIK ${ }^{1} \&$ PENNY J. GULLAN ${ }^{2}$ \\ ${ }^{1}$ Instituto Capixaba de Pesquisa, Assistência Técnica e Extensão Rural - INCAPER, Rua Afonso Sarlo 160, \\ CEP 29052-010, Vitória, Espírito Santo,Brasil, e-mail: markculik@hotmail.com; \\ ${ }^{2}$ Department of Entomology, University of California, One Shields Avenue, Davis, CA 95616-8584, USA, \\ e-mail:pjgullan@ucdavis.edu.
}

\begin{abstract}
Three mealybug (Hemiptera: Pseudococcidae) plant pest species: Dysmicoccus boninsis (Kuwana), Phenacoccus solenopsis Tinsley, and Pseudococcus viburni (Signoret), are recorded for the first time in the state of Espírito Santo, Brazil. This is the first record of Phenacoccus solenopsis in Brazil, where it was found infesting tomato plants. The species Antonina graminis (Maskell), a common pest of Bermuda grass, and Dysmicoccus brevipes (Cockerell), a major pest of pineapple, also were encountered.
\end{abstract}

Key words: Antonina graminis, Dysmicoccus boninsis, Dysmicoccus brevipes, Phenacoccus solenopsis, Pseudococcus viburni, Solanum lycopersicum

Uma nova praga do tomateiro e outros registros de cochonilhas-farinhentas (Hemiptera: Pseudococcidae) no Espírito Santo, Brasil

Resumo: São registradas pela primeira vez a ocorrência das cochonilhas-farinhentas (Hemiptera: Pseudococcidae) Dysmicoccus boninsis (Kuwana), Phenacoccus solenopsis Tinsley, e Pseudococcus viburni (Signoret) no estado do Espírito Santo. Destaca-se que o registro de Phenacoccus solenopsis, encontrada no tomateiro, é o primeiro no Brasil. Também foram encontradas em capim Bermuda a espécie Antonina graminis (Maskell) e em abacaxi e abóbora a espécie Dysmicoccus brevipes (Cockerell), ambas já relatadas no estado do Espírito Santo.

Palavras-chave: Antonina graminis, Dysmicoccus boninsis, Dysmicoccus brevipes, Phenacoccus solenopsis, Pseudococcus viburni, Solanum lycopersicum. 
Mealybugs (Hemiptera: Pseudococcidae) are important plant pests worldwide (McKenzie 1967; Williams 1985; Williams \& Granara de Willink 1992; Miller et al. 2002, 2005b). Their feeding may cause leaf yellowing, defoliation, reduced plant growth, and in some cases death of plants. Indirectly, they may also damage plants by serving as vectors of plant diseases. In addition, production of honeydew contributes to the development of sooty mold that decreases photosynthesis and may reduce the marketability of plant products such as fruits. Besides direct and indirect damage to crops, mealybugs are also of quarantine concern, adding to costs of production to prevent or eliminate their presence on plants and produce.

Information on the occurrence and distribution of mealybug species in Brazil is limited. For example, Santa-Cecília et al. (2002) documented the presence of two species of mealybugs that had not previously been known to occur on coffee in Brazil, and noted the need for additional survey and taxonomic studies on such pests in this area. Papaya is also an economically important crop in the Brazilian state of Espírito Santo. Worldwide, at least nine species of mealybugs have been recorded as pests of papaya, of which five occur in Brazil (Culik et al. 2003) but none has been recorded previously on papaya in this country (Silva et al. 1968; Medina et al.1989). Of 64 mealybug species recorded from Brazil (Ben-Dov et al. 2005), only four have previously been identified from Espírito Santo (Williams \& Schuster 1970; Silva et al. 1968; Scardini 1983; Santa-Cecília et al. 2002). Here we document new mealybug records from agricultural and horticultural plants in Espírito Santo.

\section{Materials and methods}

As part of efforts for development of integrated production of papaya, Carica papaya L., and other crops in Brazil (Martins et al. 2003), mealybugs were collected during 20032005 from various plants in Espírito Santo (ES) to identify the species present in this area. Mealybug specimens were collected when noticed on plants during fieldwork or other activities of the first author and from a sample brought to INCAPER (Espírito Santo rural research and extension organization) for identification. Bermuda grass, sugarcane, and pineapple plants at a collection site in Manguinhos, ES, where mealybugs were collected in 2004, were observed until March 2005. In 2005, tomato plants from which mealybugs were collected were observed during January to March.

All mealybug specimens were slide-mounted for identification using the method outlined in Williams \& Granara de Willink (1992), except that xylene was used instead of clove oil. Voucher specimens of these insects are deposited in the arthropod collections of INCAPER, Vitória, Espírito Santo; and the Bohart Museum of Entomology (BME), Department of Entomology, University of California, Davis, California, U.S.A. 
Three mealybug species not reported previously from Espírito Santo were found (Table 1) as well as two other species that have been recorded previously in the state. Antonina graminis (Maskell) was collected from heavily infested Bermuda grass (Cynodon dactylon) from the lawn of a home in Manguinhos, municipality of Serra, Espírito Santo, in May 2004. At the same site, in the garden of the same home, Dysmicoccus boninsis (Kuwana) was collected under the leaf sheaths of sugarcane (Saccharum officinarum) in April 2004, and Dysmicoccus brevipes (Cockerell) was collected from the base and roots of pineapple plants (Ananas comosus) in June 2004. Both D. boninsis and D. brevipes were common on a variety of the respective sugarcane and pineapple host plants at the collection site. A few specimens of D. brevipes were found also in Vitória in April 2004 on a pumpkin (Cucurbita pepo) that had been grown at the Manguinhos site. Pseudococcus viburni (Signoret) was collected from organically grown potatoes (Solanum tuberosum) purchased in Vitória from a farmer from the municipality of Santa Maria de Jetibá, Espírito Santo. Specimens of Phenacoccus solenopsis Tinsley were identified first from a tomato (Solanum lycopersicum) plant sample collected from a home garden in Vitória in October 2003. Subsequently, in January 2005, the species was noticed on tomato plants at a second home garden site in Vitória and on tomato and several weed plants in Manguinhos. Although A. graminis, D. boninsis, D. brevipes, and P. viburni have been found previously in Brazil, D. boninsis and P. viburni appear to be less well known and this is the first record of these species in Espírito Santo.

TABLE 1. Records of mealybugs (Hemiptera: Pseudococcidae) collected from Espírito Santo (ES), Brazil.

\begin{tabular}{lccc}
\hline \multicolumn{1}{c}{ Mealybug Species } & $\begin{array}{c}\text { Collection } \\
\text { Location }\end{array}$ & $\begin{array}{c}\text { Collection } \\
\text { Date }\end{array}$ & Host Plant \\
\hline Antonina graminis (Maskell) & Manguinhos, Serra, ES & 31 May 2004 & Cynodon dactylon \\
$\begin{array}{l}\text { Dysmicoccus boninsis (Kuwana) } \\
\text { Dysmicoccus brevipes (Cockerell) }\end{array}$ & Manguinhos, Serra, ES & 19 Apr. 2004 & Saccharum officinarum \\
D. brevipes & Manguinho, ES & 4 Apr. 2004 & Cucurbita pepo \\
Pseudococcus viburni (Signoret) & Vitória, ES & May 2004 & Solanum tuberosum \\
Phenacoccus solenopsis Tinsley & Vitória, ES & Oct. 2004 & Solanum lycopersicum \\
Ph. solenopsis & Manguinhos, Serra, ES & 3 Jan. 2005 & S. lycopersicum \\
Ph. solenopsis & Vitória, ES & 11 Jan. 2005 & S. lycopersicum \\
Ph. solenopsis & Manguinhos, Serra, ES & $\sim 15$ Dec. 2004 & Unidentified weed \\
Ph. solenopsis & Manguinhos, Serra, ES & 9 Jan. 2005 & Unidentified weed \\
& & & (Spermacoce sp.?) \\
\hline
\end{tabular}


Antonina graminis (Rhodesgrass mealybug) has a cosmopolitan distribution and is widespread in Brazil (Williams \& Schuster 1970). Hosts of A. graminis include several species in the family Cyperaceae and a wide variety of grasses (Poaceae), including agriculturally important species such as sorghum, and this mealybug has been noted as a pest of sugarcane and Bermuda grass (Ben-Dov 2004a). The adult female of A. graminis has a purplish-brown, oval, sac-like body lacking appendages, and is generally covered by a white or yellowish, waxy, felt-like sac (McKenzie 1967; Miller et al. 2005a). Despite the heavy infestation of $A$. graminis at the site sampled in this study, Bermuda grass continued to grow well throughout most of the lawn area except in areas, such under the eaves of the house, where the grass was apparently also stressed by other factors such as shade and lack of water.

Dysmicoccus boninsis (gray sugarcane mealybug) has a cosmopolitan distribution and has been found previously in Brazil in Bahia, Minas Gerais, Pernambuco, Rio de Janeiro, and São Paulo states (Silva et al. 1968). Its hosts include many plants in at least nine families, including a wide variety of grasses (Poaceae) and it is known as a pest of sugarcane (Ben-Dov 2004b). In contrast to species such as P. viburni, taxonomically, D. boninsis is considered to be a distinctive species (Williams \& Granara de Willink 1992). The live appearance of adult females of $D$. boninsis ranges from purplish-brown to gray with white powdery wax covering the body and wax filaments usually limited to short terminal abdominal filaments (Zimmerman 1948; Kawai 1980). Although the species was common on the sugarcane plants examined in this study, no significant damage to the plants was apparent and production was considered acceptable for home consumption.

Dysmicoccus brevipes (pineapple mealybug) is a pantropical pest of pineapple (Mau \& Kessing 1992). It is found throughout Brazil (including Espírito Santo) where it is commonly known as the "cochonilha do abacaxi" (Silva et al. 1968; Scardini 1983; Ben-Dov 2004c). D. brevipes is polyphagous and has been recorded from a very wide range of host plant species besides pineapple, including Cucurbitaceae (Ben-Dov 2004c). Adult females of $D$. brevipes have plump, convex, pinkish bodies, covered with white powdery wax, surrounded by 17 pairs of short wax filaments; the terminal filaments are longer than the lateral filaments but less than half as long as the body (Zimmerman 1948; Mau \& Kessing 1992; Miller et al. 2005a). This species is especially important as a vector of pineapple mealybug wilt disease (Zimmerman 1948; Beardsley 1965; Mau \& Kessing 1992). All of about a dozen pineapple plants at the Manguinhos collection site appeared to be infested by $D$. brevipes and had developed symptoms of pineapple mealybug wilt disease (wilting of leaves, with little or no growth of the plants in the months following the initial observation of the infestation).

Pseudococcus viburni (obscure mealybug) is a cosmopolitan species, very similar taxonomically to Pseudococcus maritimus (Ehrhorn), and has been recorded previously in Brazil (as P. maritimus) only in Minas Gerais, Rio de Janeiro, and São Paulo states (Hambleton 1935; Lepage 1938; Williams \& Granara de Willink 1992). This species has a very 
broad host range including economically important crops such as apple, citrus, grapes, and tomato, as well as papaya and potato (Ben-Dov 2004e). In life, adult females of $P$. viburni are pinkish-purple to gray, generally lightly dusted with white powdery wax, with short, fine lateral wax filaments and one pair of long terminal wax filaments usually more than half as long as the body (McKenzie 1967; Miller et al. 2005a).

Phenacoccus solenopsis (solenopsis mealybug) was described originally from the U.S. in 1898 and it remained known only in the U.S., where it is widespread, until 1992 (BenDov 2004d). In 1992, it was reported in Central America, the Caribbean, and Ecuador (Williams \& Granara de Willink 1992). Larraín (2002) recently noted the species as a pest of Solanum muricatum in Chile, and we now record P. solenopsis for the first time in Brazil. It is uncertain if this sequence represents a true, recent expansion in geographic distribution of the species from North America to South America or is simply a coincidence of collection and identification efforts. The species has been found previously on a relatively wide variety of host plants including species in economically important families such as Cucurbitaceae and Fabaceae as well as Solanaceae, however, the present work is the first published record of tomato as a host for P. solenopsis (R.J. Gill, California Department of Food and Agriculture, personal communication, indicates that he has unpublished records of this species from tomato).

Williams \& Granara de Willink (1992) note that P. solenopsis is very similar in appearance (microscopically) to Phenacoccus solani Ferris and Phenacoccus defectus Ferris. However, the live appearance of $P$. solenopsis differs from these other two species in that the adult female of $P$. solenopsis generally has paired dark spots and/or stripes dorsally (Fig. 1), whereas the females of the other two species appear to be uniformly white dorsally (Miller et al. 2005a). P. solenopsis usually has short lateral wax filaments and slightly longer terminal wax filaments (less than half as long as the body).
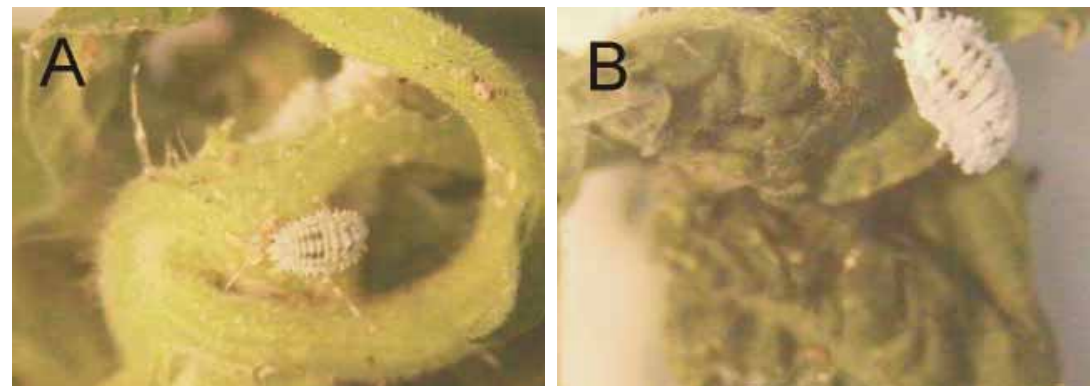

FIGURE 1. Typical live appearance of the adult female of $P$. solenopsis and infested tomato with associated symptoms of deformation and distortion of the terminal growth; A, twisting and curling of stems; B, leaf wrinkling and puckering (photographs January 2005, Manguinhos, ES, MPC).

Although P. solenopsis was described originally from specimens collected from plant roots (Ben-Dov 2004d) and is referred to as a "soil mealybug" by Lorraín (2002), in the present study the species was observed only on stems and leaves of plants (although no 
attempt was made to determine if roots of plants were infested). Infestations on tomato plants were associated with noticeable deformation and distortion of the terminal growth, consisting of twisting and curling of stems and leaves, and leaf wrinkling and puckering (Fig. 1). Osborne (2005) demonstrates similar damage caused by P. solenopsis to hibiscus. $P$. solenopsis was first noticed on the tomato plants examined in this study because of the very distinct distortions of the foliage.

Although symptoms of stem twisting and leaf puckering initially were very noticeable on infested tomato plants, the extent to which $P$. solenopsis otherwise affects plant growth and production is not clear. In Vitória, after the initial infestation was noticed on three young plants beginning to flower and set fruit in January 2005, control was attempted by pruning out heavily infested stems and leaves and removing the mealybugs by hand. By the end of February, the mealybug infestation was again noticeable, but the plants had continued to grow vigorously, flower, and set fruit until early March (when observations ended); overall, the plants appeared to be healthy despite the mealybug infestation. The extent to which $P$. solenopsis may have affected the health and production of the tomato plants at Manguinhos is also unclear because the plants were stressed by many other factors (low soil fertility, shade, lack of water). These tomato plants had mostly died by 1 March 2005, apparently due to stem borers and otherwise poor growing conditions at the site.

Tomato plants exhibiting symptoms similar to those associated with $P$. solenopsis (stem curling and leaf puckering) and that appeared to be infested with this insect have been observed in the commercial tomato growing region of Espİrito Santo (J.A. Ventura, INCAPER, personal communication), but additional research is needed to verify the distribution and potential impact of this pest. Phenacoccus solenopsis was found on common weeds in Manguinhos indicating that crops may become infested by mealybugs originating from nearby weeds.

The records reported here indicate that the mealybugs $D$. boninsis, P. solenopsis, and P. viburni are common and potentially important pests in Espírito Santo. The fact that the cosmopolitan species D. boninsis and $P$. viburni were found with relatively little effort in apparently well established populations suggests that the lack of previous records of these species in Espírito Santo reflects a lack of study of this group of insects in this area. Since P. solenopsis has not been noted previously as a pest of tomato, further research on this species and its effects on this economically important crop is especially warranted.

\section{Acknowledgements}

We thank J.A. Ventura, INCAPER, for providing one of the samples of the insects reported in this research and for helpful suggestions in reviewing this publication, D.R. Miller, USDA, Beltsville, for commenting on a draft of the manuscript, and R.J. Gill, California Department of Food and Agriculture, for providing information on the hosts of Phenacoc- 
cus solenopsis in California. We also are grateful to T. Kondo, University of California at Davis, for assistance with slide-mounting and checking identifications of some mealybug samples. The Conselho Nacional de Desenvolvimento Científico e Tecnológico-CNPq provided financial support for this work. P.J. Gullan was supported in part by Hatch funding from the California Agricultural Experiment Station.

\section{References}

Beardsley, J.W. (1965) Notes on the pineapple mealybug complex, with descriptions of two new species (Homoptera: Pseudococcidae). Proceedings of the Hawaiian Entomological Society, 19, 55-68.

Ben-Dov, Y. (2004a) ScaleNet, Antonina graminis. Available from: http://198.77.169.79/catalogs/ pseudoco/Antoninagraminis.htm (accessed 9 September 2004).

Ben-Dov, Y. (2004b) ScaleNet, Dysmicoccus boninsis. Available from: http://198.77.169.79/catalogs/pseudoco/Dysmicoccusboninsis.htm (accessed 9 September 2004).

Ben-Dov, Y. (2004c) ScaleNet, Dysmicoccus brevipes. Available from: http://198.77.169.79/catalogs/pseudoco/Dysmicoccusbrevipes.htm (accessed 9 September 2004).

Ben-Dov, Y. (2004d) ScaleNet, Phenacoccus solenopsis. Available from: http://198.77.169.79/catalogs/pseudoco/Phenacoccussolenopsis.htm (accessed 9 September 2004).

Ben-Dov, Y. (2004e) ScaleNet, Pseudococcus viburni. Available from: http://198.77.169.79/catalogs/pseudoco/Pseudococcusviburni.htm (accessed 9 September 2004).

Ben-Dov, Y., Miller, D.R. \& Gibson, G.A.P. (2005) ScaleNet, Scales in a Country Query Results. Available from: http://198.77.169.79/scalecgi/region.exe?region=T\&family=Pseudococcidae $\&$ country $=$ BRA $\&$ genus $=\&$ intro $=$ A\&detail $=$ No\&subunit $=\&$ regname $=$ Neotropi -

cal\&ctryname $=\&$ action $=$ Submit + Query \&querytype $=$ Country + Query $\quad($ accessed 2 March 2005).

Culik, M..P., Martins, D. dos S. \& Ventura J.A. (2003) Índice de Artrópodes Pragas do Mamoeiro (Carica papaya L.). INCAPER, Vitória, Espírito Santo, Brazil. 48 pp.

Hambleton, E.J. (1935) [Notes on Pseudococcinae of economic importance in Brazil with a description of four new species.] Notas sobre Pseudococcinae de importancia economica no Brasil com a descripção de quatro especies novas. (In Portuguese). Archivos do Instituto Biologico, São Paulo 6, 105-120.

Kawai, S. (1980) Scale Insects of Japan in Colors. (In Japanese). National Agricultural Education Association, Tokyo, $455 \mathrm{pp}$.

Larraín, P. (2002) Incidencia de insectos y ácaros plagas en pepino dulce (Solanum muricatum Ait.) cultivado en la IV Región, Chile. Agricultura Técnica, 62, 15-26.

Lepage, H.S. (1938) Catálogo dos Coccídeos do Brasil. (In Portuguese). Revista do Museu Paulista São Paulo, 23, 327-491.

Martins, D. dos S., Yamanishi, O.K. \& Tatagiba, J. da S. (2003) Normas Técnicas e Documentos de Acompanhamento da Produção Integrada de Mamão, (Documentos, 120). Vitória, INCAPER, $60 \mathrm{p}$.

Mau, R.F.L. \& Kessing, J.L.M. (1992) Dysmicoccus brevipes (Cockerell). Available from: http:// www.extento.hawaii.edu/kbase/crop/Type/d_brevip.htm (accessed 1 March 2005).

McKenzie, H.L. (1967) Mealybugs of California with Taxonomy, Biology, and Control of North American Species (Homoptera: Coccoidea: Pseudococcidae). University of California Press, Berkeley, $526 \mathrm{pp}$.

Medina, J.C., Bleinroth, E.W., Sigrist, J.M.M., Martin, Z.J. de, Niscida, A.L.A.C., Baldini, V.L.S., 
Leite, R.S.S.F. \& Garcia, A.E.B. (1989) Mamão: Cultura, Matéria-prima, Processamento e Aspectos Econômicos, 2nd. ed. Campinas, ITAL, 367pp.

Miller, D.R., Miller, G.L. \& Watson, G.W. (2002) Invasive species of mealybugs (Hemiptera: Pseudococcidae) and their threat to U.S. agriculture. Proceedings of the Entomological Society of Washington, 104, 825-836.

Miller, G.L, Miller, D.R., Limones, E.M., Gill, R.J., Carlson, R.W. (2005a) The United States National Collection of Scale Insect Photographs. Available from: http:// www.sel.barc.usda.gov:591/scale_slide/slide_frame.htm (accessed 22 March 2005).

Miller, D.R., Miller, G.L., Hodges, G.S. \& Davidson, J.A. (2005b) Introduced scale insects (Hemiptera: Coccoidea) of the United States and their impact on U.S. agriculture. Proceedings of the Entomological Society of Washington, 107, 123-158.

Osborne, L.S. (2005) Mealybugs. Available from: http://www.mrec.ifas.ufl.edu/lso/Mealybugs.htm (accessed 1 March 2005).

Santa-Cecilia, L.V.C., Reis, P.R. \& Souza, J.C. (2002) About the nomenclature of coffee mealybug species in Minas Gerais and Espírito Santo States, Brazil. [Sobre a nomenclatura das espécies de cochonilhas-farinhentas do cafeeiro nos Estados de Minas Gerais e Espírito Santo.] Neotropical Entomology, 31, 333-334.

Scardini, D.M.B. (1983) Eficiência de Inseticidas no Controle da Cochonilha do Abacaxizeiro no Espírito Santo (EMCAPA - Pesquisa em Andamento, 15). EMCAPA, Cariacica, 4 pp.

Silva, A.G.A., Gonçalves, C.R., Galvão, D.M., Gonçalves, A.J.L., Gomes, J., Silva, M. do N. \& Simoni, L. de (1968) Quarto Catálogo dos Insetos que Vivem nas Plantas do Brasil seus Parasitos e Predadores. Parte II, $1^{\circ}$ Tomo. Rio de Janeiro, Ministério da Agricultura, $622 \mathrm{pp}$.

Williams, D.J. (1985) Australian Mealybugs. British Museum (Natural History), London, $431 \mathrm{pp}$.

Williams, D.J. \& Granara de Willink, M.C. (1992) Mealybugs of Central and South America. CAB International, London, England, 635 pp.

Williams, R.N. \& Schuster, M.F. (1970) Cochonilha dos capins (Antonina graminis) no Brasil. I. Distribuição e plantas hospedeiras. Pesquisa Agropecuária Brasileira, 5, 215-218.

Zimmerman, E.C. (1948) Homoptera: Sternorrhyncha. Insects of Hawaii, 5, 1-464. 